\title{
PROBLEM OF POSSIBLE RATIONAL METAPHYSIS ACCORDING TO IBN KHALDUN
}

\author{
Hasan Tanriverdi \\ Doç. Dr., Ordu Üniversitesi, İlahiyat Fakültesi, İslam Felsefesi Anabilim Dalı \\ Assc. Prof., Ordu University, Faculty of Theology, Department of Islamic Philosophy \\ Ordu, Turkey \\ hasantanriverdi@odu.edu.tr \\ orcid.org/ 0000-0001-8549-7746
}

\begin{abstract}
The claim which human is a being that comes to the soul and body and origin of the soul comes from the extrasensory universe, throughout the history of thought human always kept alive the subject of ontological and epistemological relation with this world. Because of this is tending of human epistemological interest metaphysical universe which there is no sensory perception about it, as well as sensual world which subject to sense. This brings along with philosophical arguments such as the source, the limit of knowledge, the possibility of knowledge of the metaphysical universe, if it is possible this can be achieved which epistemological capabilities and what is the truth value of this knowledge. al-Kındi, al-Farabi, Ibn Sînâ, and Ibn Rushd known as Peripatetic Philosophers in the tradition of Islamic philosophy, appear to be as the most important representatives of rational metaphysics. Because they have tried to base such metaphysical matters on the reason, especially in the existence and attributes of God, prophecy, creation and resurrection. Their attempts of reasonal justification has been criticized, by many thinkers particularly the al-Gazzali, on the grounds that metaphysical issues are outside of reason comprehension area. This work focuses on the views of Ibn Khaldun who one of the critical thinkers of the Peripatetics Philosophers, rational metaphysics and to base by reason whether or not possible the basic issues of metaphysical.
\end{abstract}

Keywords: Philosophy of Religion, Ibn Khaldun, Metaphysic, Revelation, Inspiration, Reason, Sense.

\section{İbn Haldûn’a Göre Rasyonel Metafiziğin İmkânı Sorunu \\ Öz}

İnsanın ruh ile bedenden meydana gelen bir varlık olduğu ve ruhunun orijin itibariyle duyulur üstü âlemden geldiği iddiası, düşünce tarihinde insanın bu âlemle ontolojik ve epistemolojik ilişkisi meselesini daima canlı tutmuştur. İnsanlığın epistemolojik ilgisinin duyulara konu olan görünen âleme yöneldiği kadar hakkında hiçbir duyusal algının mümkün olmadığı metafiziksel âleme de yönelmesi bundan dolayıdır. Bu da bilginin kaynağı, sınırı, metafiziksel âlemin bilgisinin imkânı, eğer mümkünse bunun hangi epistemolojik yetiler ile elde edilebileceği ve bu bilginin doğruluk değerinin ne olduğu gibi felsefî tartışmaları beraberinde getirmiştir. İslam felsefesi geleneğinde Meşşâî filozoflar olarak bilinen Kindî, Fârâbî, İbn Sînâ ve İbn Rüşd rasyonel metafiziğin en önemli temsilcileri olarak karşımıza çıkmaktadır. Çünkü onlar başta Tanrı'nın varlı̆̆ı ve sıfatları, peygamberlik, yaratma ve yeniden dirilme olmak üzere bu tür metafiziksel meseleleri akıl ile temellendirmeye çalışmışlardır. Onların bu aklî temellendirme 
teşebbüsleri, Gazzâlî başta olmak üzere birçok düşünür tarafından, metafiziksel meseleler aklın kavrama alanının dışında kaldığı gerekçesiyle eleştirilmiştir. Bu çalışmada, Meşşâi filozofları eleştiren düşünürlerden biri olan İbn Haldûn'un rasyonel metafizik hakkındaki görüşleri, metafiziğin temel meselelerinin akılla temellendirilmesinin mümkün olup olmadığ konusundaki fikirleri üzerinde durulacaktır.

Anahtar Kelimeler: Din Felsefesi, İbn Haldûn, Metafizik, Vahiy, Keşf, Akıl, Duyu.

\section{INTRODUCTION}

Ibn Khaldun (1332-1406), one of the foremost Muslim philosophers of the $14^{\text {th }}$ century, has made evaluations related to transferred and rational sciences, along with many social subjects and issues. Under the title of rational sciences, he mentioned Logic, Physics, Metaphysics and Mathematical sciences (geometry, arithmetic, music, and astronomy), and he emphasized on fields, methods, means and primary principles of these. In this direction, he has expressed his opinions on which knowledge sources would provide us with accurate and valid information in understanding human experience fields and the extrasensory universe. However, Metaphysics is encountered as the most much-debated discipline, both in the West and the Islamic world.

The name Metaphysics was given by Aristo's followers to his work in which he discussed subjects such as essence, causality, nature of existence and God's existence while his works were being sorted out, due to the fact that this work came right after the work related to physics (he called this work "Peri tes Protes Philosophia"). In this manner, metaphysics has initially used in the meaning of post-physics, above-physics or beyond-physics. While physics has examines natural objects that can be sensed, metaphysics elaborates on the reality beyond sensual natural objects. ${ }^{1}$ The fact that it has attempted to ultimately explain the existence issue and that its research subject was brought "the first and the last cause of existence", as many speculations about metaphysics with it.

Aristo reached the idea of the the Prime Mover who does not move, with reference to the notion that there should be an eternal-everlasting essence that is the initiator of the movement in the universe. Hence starting from him, the term of God has become the most fundamental term in metaphysics. For example in the medieval philosophy; God's existence and

\footnotetext{
${ }^{1}$ Emest Von Aster, İlkçă̆ ve Ortaçağ Felsefe Tarihi, trans. Vural Okur, (İstanbul: İm Yayınları, 1999), 205.
} 
titles, God- universe relationship, the issues of creation and evil have been the primary and fundamental problems of philosophy. ${ }^{2}$

As for the Islamic World, Peripatetic Philosophers who followed Aristo have been the foremost defenders of his thoughts and rational metaphysics. Ibn Khaldun has opposed these rational metaphysics efforts and expressed his criticism toward them. Before proceeding to his criticism and evaluations about this, the subject would be better understood if we were to exhibit his thoughts about knowledge, nature of knowledge, its type, its source, and whether it is possible or not to have knowledge about various platforms of existence. Therefore, we will initially look answers to the questions such as: What is knowledge according to Ibn Khaldun? Is it possible to reach definite knowledge? What is the capability that provides us with definite knowledge? What can we know with it, in other terms, what does this capability include and what are its limits?

\section{THE ISSUE OF KNOWLEDGE AND ITS SOURCE}

In the literature, epistemology (knowledge philosophy) is defined as the product that is the result of the relationship of the subject to the object for a certain purpose, the thing that is comprehended, justified true belief. ${ }^{3}$ While Ibn Khaldun defined knowledge as the entirety of provable theses about objects. For him, true knowledge is the knowledge that complies with the fact it describes. ${ }^{4}$ This is kind of knowledge consists of thought or attestation of the essence. While thought consists of simple a cognition that is not decision, attestation means deciding something's certainty with another thing. Thus, it is understood that intellect has two activities in obtaining knowledge. First one of these is to combine with objects that are alike in a way that they form a composition and to generate a corresponding universal

\footnotetext{
2 Cevher Şulul, "Metafiziğin Tarihsel Evrimi", Harran Üniversitesi Illahiyat Fakültesi Dergisi 11/5 (2003), 60-62.

3 Ahmet Cevizci, Felsefe Terimleri Sözlüğü, (İstanbul: Paradigma Yayınları, 2003), 62.

4 Ahmet Arslan, İbn Haldûn'un İlim ve Fikir Dünyası, (Ankara: Kültür Bakanlığı Yayınları, 1987), 467; Ülker Öktem, “İbn Haldûn'un Felsefe-Din İlişkisine Bakışı”, Kayg̨ Uludă̆ Üniversitesi FenEdebiyat Fakültesi Felsefe Dergisi 22 (2014), 69; İbn Haldûn, Mukaddime, trans. Süleyman Uludağ, (İstanbul: Dergâh Yayınları, 2017), 886. Although we make up to the tittle's work of Ibn Haldun's The Muqaddimah the greatets extent possible, we have benefited from the translations made by Süleyman Uludağ and Zakir Kadiri Ugan. For this reason on footnotes, we will give by title's The Muqaddimah original of work, as for translations by title's Mukaddime and with the translator's name, in order to avoid confusion in places where we benefit from translation.
} 
form. In this way, knowledge is obtained about sensual objects that are subjects in the composition. Second is to attribute something to another thing, to affirm that thing in the other. This is called attestation and this kind of decisions presents certainty or presumption. The function of this kind of cognition is to comprehend the truth about objects. ${ }^{5}$ Therefore knowledge is revelation truth for those who are opinion and prudence by spacing curtain of the truth. ${ }^{6}$

It is seen that Ibn Khaldun also adopts the knowledge definition of Peripatetic Philosophers. ${ }^{7}$ Thought, which is meaning the design of object in the mind, is about conceive something without making a positive or negative statement; while attestation means making a judgment about a fact or an event. In other terms, thought is just a conceive activity without deciding, while there is deciding in attestation. In this respect, thought or cognition comes first in the process of obtaining knowledge about existence.

Ibn Khaldun defines cognition as the state of consciousness that occurs in the subject about external things. Such like state of consciousness only occurs in people and animals in the entire of universe. Senses are the leading causes for this cognition to occur in them. ${ }^{8}$ The sensory and the conscious aspects that, we encounter in knowledge also indicates the material and the spiritual aspects of people. Even if each of these aspects has unique cognition forms, the element that comprehends is the spiritual aspect in both of them. This element sometimes conceives spiritual existence that is similar to it, and sometimes material existence. ${ }^{9}$ Then case, people have another aspect separate from its material aspect called the spirit, which is the source of the reason and the ability to think.

\footnotetext{
5 İbn Haldûn, Mukaddime, haz. Süleyman Uludağ, 886.

6 İbn Haldûn, Mukaddime, trans. Zakir Kadiri Ugan, (İstanbul: MEB Yayınları, 1997), 1: 6.

7 Fârâbî, "Felsefenin Temel Meseleleri", İslâm Filozoflarından Felsefe Metinleri içinde, trans. Mahmut Kaya, (İstanbul: Klasik Yayınları, 2003), 117; İbn Sînâ, Dânişnâme-i alâ̂-alâ̂̂ hikmet, trans. Murat Demirkol, ed. Gürbüz Deniz, (İstanbul: TC Türkiye Yazma Eserler Kurumu Başkanlığı Yay., 2013), 262 (63a); İbn Sînâ, Necât, nşr. Muhyiddin Sabri Kurdî, (Kahire: y.y. 1938), 3; İbn Rüşd, Faslu'l-makâl fî mâ beyne'l-hikmeti ve'ş-şerî'ati mine'l-ittisâl, enq. Muhammed Ammar, (Kahire: Daru'l mea'rif, 1119), 54.

8 cf., Ibn Haldûn, The Muqaddimah, enq.. Abdüsselam eş-Şeddâdî, (b.y. Dâru'l-beydâ, 2005), 1: 154-166. Fârâbî, Ârâu ehli'l medîneti'l fâdıla ve mutedâddâtihâ, takd. Ali Bû Mulhim, (Beyrût: Dâr ve mektebetu'l hilâl, 1995), 103; İbn Sînâ, De Anima, nşr. Fazlur Rahman, (London: y.y., 1970), $41-44$

9 Ibn Haldûn, The Muqaddimah, 2: 343.
} 
Ibn Khaldun, who accepts senses as some of the sources that provide true knowledge, classifies them as internal and external senses. External senses (el-hissu'z-zâhir) are seeing, hearing, touching, tasting and smelling; while internal senses (el-hissu'l-bâtın) consist of common sense, imagination (muhayyile), suspicion, memory and thinking (nefs-i nâtika). ${ }^{10}$

\section{INTERNAL AND EXTERNAL SENSES}

According to Ibn Khaldun, people and animals recognize objects in the sensual world thanks to external senses. These senses, which have the ability to form an impression of objects and start the knowledge acquisition process about the physical world. ${ }^{11}$ Therefore essential in cognition is that objects are conceived by external senses. ${ }^{12}$ In the knowledge acquisition of external senses, there are two important functions: acquisition of perceptions about objects and thus setting other knowledge abilities in motion. Accordingly, external senses are abilities that provide the required raw material for knowledge.

For impressions provided by external senses to become knowledge, they must be processed by internal senses. In this process, impressions acquired from objects by external senses initially go through the common sense which comes first among internal senses. Common sense perceives the information provided by external senses in a different way, as a "whole". From there, this information is transferred to the imagination power, which isolates them from their material form in the external world and gives them forms that are suitable to this universe. From there, it is transferred to suspicion and memory powers. While the suspicion power comprehends meanings about sensual and particular events, memory serves as the storage that keeps all this information. ${ }^{13}$ As it is understood from the statement above, the physical world is the area where the senses are active and provide us with knowledge. Therefore, we can only conceive material things, objects with senses.

\footnotetext{
${ }^{10}$ Peripatetic Philosophers were also defended, in which the senses provided the right information and divided into two in the form of internal and external senses. cf., Fârâbî, Ârâu ehli'l medîneti'l fâdıla ve mutedâddâtihâ, 41-44; Ibn Haldûn, The Muqaddimah, 1: 154-166.

${ }^{11}$ Ibn Haldûn, The Muqaddimah, 1: 166, 2: 443; İbn Haldûn, Mukaddime, trans. Zakir Kadiri Ugan, 1: 264; İbn Haldûn, Mukaddime, trans. Süleyman Uludağ, 766.

12 İbn Haldûn, Mukaddime, trans. Süleyman Uludağ, 885.

${ }^{13}$ Ibn Haldûn, The Muqaddimah, 1: 154-155.
} 
It is seen that Ibn Khaldun adopts the empiricist approach to the issue that whether our knowledge is innate or not. Because according to him "people are innately ignorant, and they become wise as they acquire knowledge". ${ }^{14}$ Therefore, it would be more appropriate to say that our knowledge is not innate, and it comes from having the capacity and the ability to acquire knowledge. People have minds like "tabula rasa" at birth, and they become informed about objects using their ability to acquire knowledge, have voiced by John Locke and Ikhwan-i Safâ who almost about six hundred years ago from him ${ }^{15}$.

Ibn Khaldun has accepted experience as a source that provides true knowledge. He asserted that knowledge on the physical world, daily work, issues about nature philosophy, debates about the alm al-umran, principles of political philosophy, movement of planets and effects of stars are all products of the experience. ${ }^{16}$ Namely, political order is a natural fact that does not stem from the reason, God or another mysterious force. Movement of planets and effects of stars are known by experience, but human life is not enough for deriving results from these experiences. Because experience only transforms into knowledge or presumption that depends on its repeated several times. However, since cycles of some stars take too long, even the universe's lifetime wouldn't be enough for experiencing the recurrence of their tours. ${ }^{17}$

Ibn Khaldun, who accepting senses and experience as true knowledge sources, did not limit our knowledge capacity with these sources, and what we know with what they provide. He has applied and laid emphasis on a hierarchical classification of knowledge capacities, the intellect/reason as a capacity that exceeds senses and experience, and what they know.

\footnotetext{
14 İbn Haldûn, Mukaddime, trans. Süleyman Uludağ, 775.

${ }^{15}$ Mahmut Meçin, "İhvân-1 Safâ'da Bilgi, Bilim ve İlimlerin Sınıflandırılması”, Dicle Üniversitesi İlahiyat Fakültesi Dergisi 16/1 (2014), 431.

${ }^{16}$ Ibn Haldûn, The Muqaddimah, 1: 152-153; İbn Haldûn, Mukaddime, trans. Zakir Kadiri Ugan, 2: 443 .

${ }_{17}$ Ibn Haldûn, The Muqaddimah, 3: 187; Hilmi Ziya Ülken, İslam Düşüncesi, (İstanbul: Ülken Yayınları, 2005), 225-226; Kamil Sarıtaş, "İbn Haldûn'da Bilgi Felsefesi", Turkish Studies 9/8 (2014), 738-739.
} 


\section{1. Intellect/Reason}

The intellect associates sensory information with each other and transforms them into knowledge. The information that is provided by external senses and processed by internal senses proceed to the intellect (kuvve-i müfekkire) after passing those stages. Ibn Khaldun has stated that information that separately comes from senses are associated with each other in the intellect, thus new forms about sensual objects (mahsûsat) can be reached. As a result of mental processing of these forms, some other forms are obtained. Then the intellect is where the processes of analysis and synthesis are made on impressions from senses and forms that are acquired from them. The knowledge that can't be learned with external senses is acquired through it; ${ }^{18}$ also, science and arts are formed with it. ${ }^{19}$

Ibn Khaldun has pointed out the two main acquisitions that come with the intellect of humankind. These are; a) to build a social life on the culture of co-existence, b) to comprehend the prophet's message in order to prepare for the afterlife. Moreover other things that happen with the intellect are to reach the truth, to make right decisions and to live according to those decisions, to reveal good aspects of human nature, and to distinguish between good and bad. Therefore, this is the ability that separates humans from animals, that makes humans superior and able to realize themselves (since external senses are common in humans and animals). ${ }^{20}$ While intellect provides us with information about the existence, on the other hand, it determines moral principles toward doing what's right in our behaviors in the other.

The intellect, which is one of the key concepts of knowledge philosophy, is used in the same meaning with the reason in his system. This ability is the natural implement to conceive and comprehend reality, and it also enables right decision making. ${ }^{21}$ For the intellect to fulfill these functions, one must exceed through the stages of discerning, experimental

\footnotetext{
${ }^{18}$ Ibn Haldûn, The Muqaddimah, 1: 154-155; İbn Haldûn, Mukaddime, trans. Süleyman Uludağ, 766-768.

19 İbn Haldûn, Mukaddime, trans. Süleyman Uludağ, 886.

${ }^{20}$ Ibn Haldûn, The Muqaddimah, 1: 154-155, 2: 343; İbn Haldûn, Tasavoufun Mahiyeti (Şifâu'sSâil), trans. Süleyman Uludağ, (İstanbul: Dergah Yayınları, 1998), 39; İbn Haldûn, Mukaddime, trans. Zakir Kadiri Ugan, 1: 19; Murteza Bedir, “İbn Haldûn'un Gözüyle Nakli İlimler”, Geçmişten Geleceğe İbn Haldûn Sempozyumu içinde, (İstanbul: İsam Yayınları, 2006), 226-227.

${ }^{21}$ Hacer Âşık Ev, “İbn Haldûn ile John Locke'un Epistemoloji ile İlgili Bazı Görüşlerinin Karşılaştırılması", Ankara Üniversitesi Ĕ̆itim Bilimleri Fakültesi Dergisi 43/2 (2010), 104.
} 
and theoretical reason, each of which representing a certain phase, and adding up to the maturation of a person.

The discerning reason (akl-1 temyizî) is the reason that relates to comprehending subjects that are regulated by the natural or the arbitrary order. With this in reason, first the image of objects, and then concepts about them are acquired; most of which come from the thoughts. This reason forms the basis for people to benefit from the external world, protect themselves from harm, and sort out their daily business. Experimental reason (tecrübî akıl) is the reason that regulates relations between people, establishing social principles and etiquette. Most of these come from attestation and shape stage by stage until the desired benefit is reached. ${ }^{22}$ If the discerning reason -which develops based on subjective experiment- is supported by the experimental reason in social life, person can gain experiment of others and previous societies, alongside one's own knowledge and experience. ${ }^{23}$

As for the theoretical reason (nazarî akıl); on the sensual cognition, it is the mind that provides knowledge or presumption about non-behavioral issues. These consist of thought and attestation that are regulated based on certain rules. Because in this stage, new knowledge is reached through forming concepts or making a judgment and other knowledge is reached from there by synthesizing and composing. Therefore, sensual and extrasensory universe of existences' thoughts are acquired. What really matters here is to comprehend existence as it is with its types, distinctions, and causes. Thus, the reason becomes mature about its own truth and reaches the state of "akl-1 mahz, nefs-i müdrike", which constitutes the meaning of the truth of humans according to Ibn Khaldun. ${ }^{24}$ This ability of the nafs (soul) is "a divine grace"; and it also has other names in sharia, such as soul, heart, and nafs. Even if the mentioned concepts evoke similar meanings, it should not be forgotten that they correspond to different meanings. ${ }^{25}$

Development and maturing of the theoretical reason -which is determinant in understanding the physical world, logical reasoning, and obtaining universal and moral concepts- depend on the advancement of the

\footnotetext{
22 İbn Haldûn, Mukaddime, trans. Süleyman Uludă̆, 767, 775.

${ }^{23}$ Bedir, "İbn Haldûn'un Gözüyle Nakli İlimler", 226-227.

24 İbn Haldûn, Mukaddime, trans. Süleyman Uludağ, 766-767, 775.

25 İbn Haldûn, Tasavoufun Mahiyeti (Şifâu's-Sâil), 102.
} 
discerning and the experimental reasons, and following the cause and effect relationship in the sensual world. ${ }^{26}$ However, these senses may not occur in everyone or may not occur to the same degree. ${ }^{27}$ Another thing that must be specified here is that this distinction is analytical; experimental reason and theoretical reason cannot be distinguished in practice since they interact with each other. ${ }^{28}$

In Ibn Khaldun's epistemology, the intellect has two important functions; theoretical and practical. In its theoretical sense, it generates universal concepts that correspond with all objects of the same type and manifest their existence in the external world; by associating these concepts with each other, judgment, meaning knowledge, is reached. In its practical sense, it regulates and maintains individual and social life in accordance with moral principles. Thus, knowledge of moral and social values is reached with the intellect, along with theoretical sciences.

In Ibn Khaldun's system, the intellect and senses are not independent, but forces that are in correlation with each other. While the intellect helps sensory information to become clear, ${ }^{29}$ senses help the reason conceive. ${ }^{30}$ Since senses provide us with information on the physical world, and since the intellect processes through information provided by senses, how can one acquire information about extrasensory existence that does not physically correspond in this world? Can this existence be comprehended and founded with senses and reason? If it is not, what is the ability our source that we can comprehend the extrasensory existence with it? In this context, we will be discussing whether rational metaphysics is possible or not.

\section{THE ISSUE OF THE POSSIBILITY OF RATIONAL METAPHYSICS}

Before we move onto the issue of the possibility of rational metaphysics, we need to emphasize on the ontological distinction Ibn Khaldun predicted between existence layers. Because the hierarchical distinction between knowledge types and abilities in his epistemology are mere reflections of ontological differences he acknowledged between existence layers. In this

\footnotetext{
${ }^{26}$ Bedir, “İbn Haldûn'un Gözüyle Nakli İlimler”, 227.

${ }^{27}$ Ev, “İbn Haldûn ile John Locke'un Epistemoloji ile İlgili Bazı Görüşlerinin Karşılaştırılması”, 99.

${ }^{28}$ Kadir Canatan, “İbn Haldûn'un Eğitim Sosyolojisi”, Eski Yeni 3 (2006), 58.

29 İbn Haldûn, Tasavoufun Mahiyeti (Şifâu's-Sâil), 82-84.

${ }^{30} \mathrm{Ibn}$ Haldûn, The Muqaddimah, 2: 332-333.
} 
context, he has classified existence in three universes -the sensual world (âlemu'l-hiss), the intelligible world (âlem'ul-fikr), the world of spirit and angels (âlem-i ervah \& melâike) - and expressed that we can acquire knowledge about these three universes.

Among these, the sensual world of objects that is subject to senses and experience. While this universe's knowledge is acquired with senses, knowledge of the intelligible world -which is above it- is acquired with the theoretical reason. Because this reason reaches universal and comprehensible concepts by abstracting certain meanings from sensual entity. Thus, a form that corresponds to all concrete existence, such as the mark left by a seal on clay or wax, can appear in imagination; this abstract form is called the first reasoning. Universal concepts are re-processed by the mind, based on whether they are similar or not to other universal concepts. The process of abstracting continues until reaching concepts that correspond to all concepts and individuals, which are so universal and simple that abstracting cannot take them beyond what they are. Abstract meanings and concepts that are reached by this process are called the second reasoning. ${ }^{31}$ Second reasoning, which is a higher form, obtained by abstracting from the first reasoning. However, while there are concrete realities that correspond to the first reasoning in the external world, the second reasoning does not correspond to a concrete reality.

Ibn Khaldun has stated that our judgments, including the mental ones, are in the first reasoning that is suitable with concrete existence, and not second reasoning, which is the product of second degree abstracting. This shows that our mental judgments present certainty on the sensual platform and the sensory cognition level. Since there is maximum accord in first reasoning, it is closer to conformity. Therefore, it can be claimed that only the first reasoning conforms to the external existence. But it is more appropriate to beware than to contemplate or to reflect on this matter. Because "leaving behind unnecessary things is due to being a good Muslim". Matters relating to nature does not have importance either in terms of our religion or our living. ${ }^{32}$

While Ibn Khaldun accepts knowledge and evidence from the first reasoning as argument (burhan) that corresponds to a reality in the external

\footnotetext{
31 İbn Haldûn, Mukaddime, trans. Süleyman Uludağ, 885, 950.

32 Ibn Haldûn, The Muqaddimah, 2: 342-343; İbn Haldûn, Mukaddime, trans. Süleyman Uludağ, 952-953.
} 
world, he does not accept the knowledge from the second reasoning to be certain, since it is out of our cognition zone. Because, while the first one can be confirmed by experiment or experience, those above senses are of the intelligible and they are not open to such confirmation. Only reaching universal truths through the abstraction of the theoretical mind indicates that there is a intelligible world where it is above sensual world.

Distinguishing sensory knowledge and products of thought universal from each other, Ibn Khaldun accepts reasoning with real content that corresponds to existence as the subject of knowledge, not all kinds of abstractions. If we were to put it in Plato and Aristo's terms, he did not adopt Plato's ideas, but he adopted Aristo's forms with concrete and real content. ${ }^{33}$ Besides he viewed mental and natural possibility among accuracy criteria of knowledge, he laid emphasis on knowledge's suitableness to social and material conditions and the nature of financial relations. In this regard, the mental possibility was not enough for him, and it also required "external possibility". ${ }^{34}$

According to Ibn Khaldun, existence, which has material and immaterial aspects, is fairly broad to be comprehended by humans with all its aspects. Since God's creations are not limited by human cognition, humans can only know a part of things to be understood with its own unique intellect. ${ }^{35}$ On the other hand, for each cognition ability, existence is limited with things inside its conceiving zone. But truth does not consist of what a cognition ability signals, but above it. Therefore, people shall act with suspicion toward their own cognition and limited things they have conceived. ${ }^{36}$ Hence, we can only know qualities and symptoms of objects with senses and reason; we cannot know its own truth.

Even if Ibn Khaldun limited things we can acquire knowledge about with entities that have a reality in the external world and their qualities, he did not limit existence with those that are subjected. He has argued that there is the intelligible world above the sensual world and the world of spirit and angels above it. Is it possible to acquire knowledge about the world of spirit and angels with the reason and senses that are used to provide

\footnotetext{
33 Ahmet Arslan, İbn-i Haldun, (İstanbul: İstanbul Bilgi Üniversitesi Yayınları, 2014), 350.

${ }^{34}$ Nurullah Ardıç, "İbn Haldûn ve Weber'de Bilgi ve Bilim Sorunu”, Geçmişten Geleceğge İbn Haldûn Sempozyumu içinde, (İstanbul: İsam Yayınları, 2006), 246-247.

${ }^{35}$ Ibn Haldûn, The Muqaddimah, 3: 64, 184.

36 Süleyman Uludağ, İbn Haldûn, (Ankara: TDV Yayınları, 1993), 116; İbn Haldûn, Mukaddime, trans. Süleyman Uludağ, 822-823.
} 
knowledge about the sensual world and the intelligible world? Do these abilities provide us with certain information about the metaphysical universe?

Ibn Khaldun has stated that all philosophers think that existence can be known by the theoretical reason and mental syllogism, along with its entities, forms, causes and factors, whether they are sensual/physical or extrasensory/spiritual. Because according to philosophers, it is possible to detect the accuracy of principals' belief with the reason. Since these consist a part of mental conceiving, there is no need to transfer in order to base them. In accordance with this principle, philosophers have created the science of logic in order to distinguish right from wrong. ${ }^{37}$

Ibn Khaldun has sorted the fundamentals that are the base of the conceiving and evidence of philosophers about existence in this order: Philosophers initially reached the knowledge of matter (cism-i süflî) with senses and observation. Then they comprehended the existence of a nafs which is the source of senses and movement in living beings. Later on, thanks to the powers of the nafs, they have become aware of the mind and their conceiving has ended at that stage. By comparison with this decision they have reached about the human entity, they have decided upon the existence of the supreme celestial entity. From there, they have thought that the sphere obliged to have a nafs and a mind too, just like people, and they have accepted the number of spheres as ten. ${ }^{38}$ Our thinker, finding the argument method of philosophers commendable, did not accept arguments such as applying this method to the extrasensory zone where human thinking cannot reach and explaining the creation of the universe this way.

According to Ibn Khaldun, it is not possible to place argument on things that do not have a concrete reality on the material world. Arguments that were asserted on this type of entities are lacking and insufficient for the purpose. Since entities that are separate from matter or spiritual beings cannot directly be comprehended, they cannot be known by their persons. This situation was also expressed by some philosophers. For example, about the metaphysical universe, Plato has said "One cannot reach closeness or certainty. In this field, one can only talk of truer or more convenient, which is

\footnotetext{
37 İbn Haldûn, Mukaddime, trans. Süleyman Uludağ, 950.

38 İbn Haldûn, Mukaddime, trans. Süleyman Uludağ, 951.
} 
presumption". ${ }^{39}$ According to this, it is not possible to accept one suggested judgment as to the definite truth and to reject all others about the metaphysical universe.

Ibn Khaldun had the opinion that the claim about the mind being capable to comprehend the universe, the creation and the existence with all its details should not be accredited. "Spiritual beings, since there is a curtain between us and them, can neither be conceived, nor their mental images can be acquired by abstracting. Therefore, we are not in a state which enables us to prove their existence by asserting mental evidence or arguments."40 According to him, the reason has a limit of comprehension, and start making mistakens when it goes out of this limit, which is the limit of the sensual and intelligible world. ${ }^{41}$ Because, the reason, which tries to comprehend the metaphysical universe, comes to a state where it cannot take another step forward and returns disappointed. ${ }^{42}$

Ibn Khaldun has stated that we are lacking in comprehending the nature of God's person because he did not grant it. He did not think matters such as issues about holiness and afterlife, the nature of prophecy or divine can be proven or rejected with the reason. ${ }^{43} \mathrm{He}$ has compared the state of a person who attempts to base these with the reason to "a person who tries to weigh mountains with scales used to weigh gold". According to him, the reason is a speck that is one of the specks that God has created and cannot carry this weight. To make this effort is to waste time for nothing since it is an empty and imaginary endeavor. Therefore, all ideas and arguments asserted by philosophers on this subjects are invalid. ${ }^{44}$

Ibn Khaldun accepted that arguments and mental evidence as material conceivings, since they are based on imagination, thought and memory powers of the mind. 45 This type of human cognition implements is lacking of in hardware that can comprehend all secrets and mystery of divine and metaphysical entities by their nature. On the contrary, they

\footnotetext{
39 İbn Haldûn, Mukaddime, trans. Süleyman Uludağ, 953; Bedir, “İbn Haldûn'un Gözüyle Nakli İlimler", 227.

${ }^{40} \mathrm{Ibn}$ Haldûn, The Muqaddimah, 3: 182.

${ }^{41}$ Ibn Haldûn, The Muqaddimah, 3: 26.

42 Ibn Haldûn, The Muqaddimah, 3: 182.

${ }^{43}$ Ibn Haldûn, The Muqaddimah, 3: 30.

${ }^{44}$ Ibn Haldûn, The Muqaddimah, 3: 30-31; Arslan, İbn Haldûn'un İlim ve Fikir Dünyası, 467; Uludă̆, İbn Haldîn, 116.

45 İbn Haldûn, Mukaddime, trans. Süleyman Uludağ, 954.
} 
present an obstacle for the spirit to diffuse to this universe. External senses grow weary because they are material and connected to matter, and because they are used frequently by nafs-i natika. When tired senses cover nafs-i natika, despite the fact that the spirit is able to completely abstract itself from the body, they stop the nafs from comprehending the world of spirit and angels. ${ }^{46}$ From this, it is understood that the world of spirit and angels is a world of entities beyond time and place, which cannot be comprehended by senses and reason, and is not material.

Ibn Khaldun did not think it was possible to present conclusively proven rational evidence about the world of spirit and angels and thought that, the reason should be withdrawn from that universe. But this does not mean that, in him book, the reason and its decisions are worthless. Because humans are equipped with abilities to acquire science and arts (es-sanâi'u). ${ }^{47}$ The reason is a reliable criterion in these activity fields, and its inferences are definite and clear from mistaken. ${ }^{48}$ Therefore, what is trying to be expressed here is not that reason's decisions should not be accredited, but that its cognition is limited and it cannot reach a positive or negative deciding outside of those limits.

Ibn Khaldun viewed the method used by philosophers to get to the truth as convenient, but he thought that their results were far from definite. According to him, philosophy is not a way to definite knowledge about the world of spirit and angels, but a path of presumption and suspicion. If one can only reach presumption after all that fatigue and effort, one should suffice with the existing presumption on that matter. While importance was placed on definite evidence about this universe, it is clear that this target cannot be reached via philosophy and reason. God is the one that would get us to the truth and inform us of it. "If God were not to make us see the light, we would not be able to see it". ${ }^{49}$

Even though Ibn Khaldun has claimed that the mind cannot cover a distance in the metaphysical universe, it is true that several evidences have been asserted about basing the existence and the attributes of God in the field of Philosophy and Kalam. Some of these evidences are based on

\footnotetext{
${ }^{46}$ Ibn Haldûn, The Muqaddimah, 1: 163-164; İbn Haldûn, Mukaddime, trans. Zakir Kadiri Ugan, 2: 518 .

${ }^{47}$ Ibn Haldûn, The Muqaddimah, 3: 92.

${ }^{48}$ Ibn Haldûn, The Muqaddimah, 3: 26.

49 İbn Haldûn, Mukaddime, trans. Süleyman Uludağ, 953-956; Bedir, “İbn Haldûn’un Gözüyle Nakli İlimler", 226-227.
} 
hadith/possible existence, and some them on the order and the regularity of the universe, but all of them have adopted the cause and effect relation as a principle and tried to prove the existence and the attributes of the First Cause/God from there as follows;

Every event that takes place in a universe of creation and dissolution, whether it's ability or accident, has a preceding cause. If these causes are hudûth (creation), they will certainly be having causes too. When you go back in the chain of causes, at the final point, you reach the creator responsible for these causes. This cause, in which there is no other God, is excluded from any kind of flaw. ${ }^{50}$ Ibn Khaldun attached importance to the cause and effect relation about the physical world and social incidents but thought that this would have no benefits, but it would cause a loss when it came to the metaphysical universe. What were his concerns with this?

According to Ibn Khaldun, not all of the causes of the existence of the cosmic universe can be comprehended with the reason. Because, as you go further back in the chain of causes, causes would pile up and get more complicated. Besides, once these causes exceed our existence zone in terms of holiness, they would be outside of our cognition zone. We can only know causes that are natural and external, that are subjected to our cognition implements within a certain order. Since we have a grasp of the beginning stage and order of psychological incidents, we cannot even know the cause of each mental thoughts. These are things that are placed on our minds by God, provided that they are tied to each other. Then, an end cannot be reached by exploring causes, causes of causes and effects of those in the ocean of reason. One who does not advance to higher places because of getting caught up in causes would deserve the word blasphemy. ${ }^{51}$

Ibn Khaldun, who kept the disposing and knowledge activities of the nafs within the sensual world, stated that the field of thoughts is much broader than that. According to him, we cannot even understand all of the thoughts, let alone conceive them. If we are looking for the mystery about the fact that God has restrained us from thinking on causes and pursuing that to the end, we need to look for it there. Since it has no use but to entertain the mind and the truth cannot be reached in this way, and many

\footnotetext{
50 İbn Haldûn, Mukaddime, trans. Süleyman Uludağ, 821.

51 İbn Haldûn, Mukaddime, trans. Süleyman Uludağ, 821-823.
} 
people deviated from their aims because of this, one should give up thinking on causes and restrain from it. ${ }^{52}$

According to Ibn Khaldun, the way transcendent causes influence their effects cannot be known. Because this can be known by habit and experience. Things that are subjects of our experience are there with their causes in the external world. Nature and qualities of effects of transcendent causes are uncertain. Therefore, it is commanded that we would turn toward the doer and the inventor of all causes, by defining oneness on the subject of holiness, without paying attention to causes. Şâri', who has knowledge's extrasensory universe, is the one who best knows the issues about religion and the ways to happiness. A person's task here is to be subjected to whatever belief or action Şâri' has ordered. Thus there is no other doer than God; all reasons escalate to Him and lean on His power. Our knowledge of Him is because we have emerged from Him. That's what "To be deprived of cognition is cognition itself" means..$^{53}$

Ibn Khaldun has stated that the fact that Peripatetic Philosophers attributed all existence to the first reason and sufficed with that for basing the Necessary Being on, means that they have overlooked the degrees in God's existence. According to him, the verse that says "He creates those you don't know" 54 means that the field of existence is much broader than that. Therefore, since Peripatetic Philosophers accept the existence of the reason and the nafs and they are not aware of other existence; that is, they are in the same grade with naturalist philosophers who accept the existence of objects and matter but rejects the existence of the nafs and the reason, and say that there is nothing beyond matter. ${ }^{55}$

It is not a correct approach to categorize Peripatetic Philosophers, who have initially classified existence as material and non-material, and sorted the existence area from more competent to less, as in "The First (God), secondary (abstract reasons), active reason, nafs and form", with naturalist philosophers who view the physical world as the only reality zone. Because, in naturalism, all reality is tried to be reduced to the material, including the holy and ideal existence zone; while in Peripatetic Philosophy, true reality zone of philosophy is accepted as the extrasensory universe, where entities

\footnotetext{
52 İbn Haldûn, Mukaddime, trans. Süleyman Uludă̆, 821.

${ }^{53}$ Ibn Haldûn, The Muqaddimah, 3: 26; İbn Haldûn, Tasavvufun Mahiyeti (Şifâu's-Sâil), 39.

${ }^{54} \mathrm{Nahl}, 16 / 8$.

${ }_{55}$ Ibn Haldûn, The Muqaddimah, 2: 341; İbn Haldûn, Mukaddime, trans. Süleyman Uludağ, 952.
} 
without matter exist. In other terms, while there is no transcendent principle to explain the universe and the existence in naturalism, Peripatetic Philosophy explains that the existence of the universe with an unnatural cause, the Necessary Being. The Necessary Being exists because of himself and all things outside of Him also exists thanks to Him.

Ibn Khaldun has asserted that the issues of happiness and judgment cannot be comprehended with the theoretical reason and that one must resort to sharia for comprehending these. Ibn Sina, who was aware of this, accepted the spiritual judgment as one of the subjects that can be known by argument, while he excluded physical judgment from that. Because spiritual judgment is about one creation and the relation of a secret nature, while physical judgment is not about a constant relation. ${ }^{56}$ Ibn Khaldun did not think the views of Peripatetic Philosophers -who brought rational evidence on this- were sufficient. He has criticized the evidence they claim to be certain.

According to Ibn Khaldun, the argument asserted by philosophers did not only fulfill their purposes but also contradicts with clear decisions of religion/sharia. The only benefit of metaphysics is to strengthen the mind by trying to organize evidence. And that happens in the direction of principles that are stipulated in the science of logic and rules of the natural science. Even though syllogism and principles in the science of logic are insufficient for meeting purposes of the philosophers in theology, they are still the most reliable ones among the principles related to reasoning. ${ }^{57}$

Ibn Khaldun sees that the benefits of rational metaphysics in strengthening the mind and gaining the ability to easily deduce from premises, not in bringing in argument like philosophers have claimed. The reason for him to find the arguments asserted on this subject weak, is that we are lacking of in comprehending the persons of holy beings. Then what attitude needs to be adopted in a field that is extrasensory universe and that cannot be comprehended by the reason? Must sharia's commands be confirmed as they are in this field, without adding logical and rational evaluations on them? Do we have the ability or sources to comprehend these entities as themselves?

\section{1. Founding Of Metaphysics}

\footnotetext{
56 İbn Haldûn, Mukaddime, trans. Süleyman Uludağ, 954-956.

57 İbn Haldûn, Mukaddime, trans. Süleyman Uludağ, 956.
} 
Ibn Khaldun, who did not think rational metaphysics was possible, thought that attempts on basing this universe on the reason were in vain. On the background of this view of his, there was the thought that a person's material side would present an obstacle for establishing a full connection with the spiritual universe. Having said that, he thought that the nafs, by its nature, has a wish and a tendency to become the active thinker by abstracting itself from human capabilities and powers, therefore emulating the spiritual beings (angels) in the most supreme universe. This capability reveals itself in the most superior and competent way in prophets. ${ }^{58}$ Therefore, the metaphysical universe is not the field of the reason, but the field of revelation and faith.

According to Ibn Khaldun, "revelation comes before the reason in metaphysical matters". ${ }^{59}$ The cause for the reason's incapability to comprehend the world of spirit and angels is that these issues - and therefore vấz' $i$ sciences - are based on divine light. ${ }^{60}$ Spiritual proofs are superior to rational proofs and include them, since they surround everything, including God's knowledge and power. Therefore, one must prefer what God proclaims to human conceiving and knowledge, leave the reason aside when transference conflicts with rational evidence, believe in and be subjected to God's commands and decisions, and remain silent about what we can't understand. Besides, one must defend with rational evidence against rational innovations that cause a threat in terms of faith, as Theologians (Kelamcilar) did. ${ }^{61}$

Ibn Khaldun has stated that a revelation is a way to acquire knowledge, unique to prophets. According to him, the knowledge acquired in this way is the most superior one in terms of accuracy and degree. Nafs of prophets were created in such a disposition and they were shaped and formed around that disposition. They were cleansed of obstacles and challenges, and moral malignancy. As required by God's grace, the prophet glorifies people of his choosing by honoring them with his addressing. ${ }^{62}$ The

\footnotetext{
${ }^{58}$ Ibn Haldûn, The Muqaddimah, 2: 343.

${ }^{59}$ Ibn Haldûn, The Muqaddimah, 3: 26.

${ }^{60}$ Ibn Haldûn, The Muqaddimah, 3: 106.

${ }^{61}$ Ibn Haldûn, The Muqaddimah, 3: 106-107; Sarıtaş, “İbn Haldûn'da Bilgi Felsefesi”, 743; Bedir, “İbn Haldûn'un Gözüyle Nakli İlimler”, 227.

62 İbn Haldûn, Tasavvufun Mahiyeti (Şifâu's-Sâil), 107; Hasan Tanrıverdi “İbn Haldûn'un Vahiy Anlayışı", Insan ve Toplum Bilimleri Araştırmaları Dergisi 5/1 (2016), 78.
} 
most important characteristic of this knowledge prophets received from God about the invisible universe is that they are definite and certain.

During a revelation, prophets cut off their ties to their human qualities and their surroundings, connect with the spiritual universe without needing a sense or implement, and rise to an angel's level. Even if it's just for a blink, they reach divine universe and conceive that universe with a comprehension more than human comprehension. When this state ends, they return to the physical world after they understand what was revealed. ${ }^{63}$ The knowledge acquired from here by revelation is not the type of information that is acquired with external senses and rational inference, but a knowledge directly based on the experiences of beings in the world of spirit and angels, acquired by connecting with that universe.

Ibn Khaldun thinks that there is no conflict between the knowledge received from revelations and the knowledge acquired with the reason, experience and observation. Even if it seems like there is a conflict, he attributed that to misinterpretation of revelations. Even if it can be said that he resorted to explaining the revelations here, it is also true that he unhesitatingly accepted that revelation in a lot of issues that the reason would have difficulty understanding. ${ }^{64}$ Revelations do not depend on human attempt and effort, this is a type of knowledge that is the result of a holy grace. If the world of spirit and angels can't be known in any other way than revelations, and words of prophets, then all that is said about this universe would lose its meaning.

According to Ibn Khaldun, is it possible to know the world of spirit and angels in any other way than revelations? He sees the fact that prophets eluded their human qualities and ascended to the spiritual universe as evidence of the possibility of other people achieving this. In this context, those who isolate their nafs from material and sensory qualities reach the possibility of connecting with the divine universe and acquire knowledge about it. 65 "As the knowledge about the world of spirit and angels can be acquired via prophets, it can also be partially known by the nafs that was given to humankind but remains of this universe as of its origin". ${ }^{6}$

\footnotetext{
${ }^{63}$ Ibn Haldûn, The Muqaddimah, 1: 156-157.

${ }^{64}$ Ardıç, “İbn Haldûn ve Weber'de Bilgi ve Bilim Sorunu”, 251.

${ }^{65} \mathrm{Ibn}$ Haldûn, The Muqaddimah, 1: 158-159.

${ }^{66} \mathrm{Ibn}$ Haldûn, The Muqaddimah, 2: 343; Mina Ahmed Ebu Zeyd, el-Fikru'l-kelamî inde İbn Haldûn, (Beyrut: el-Müessesetü'l-Câmi'a, 1997), 19; Bedir, “İbn Haldûn'un Gözüyle Nakli İlimler", 226-227.
} 
Ibn Khaldun, who does not view the theoretical reason to be sufficient for basing metaphysical issues on and does not think that this field is completely faith-related. According to him, the attitude that is valid in accepting God's existence and oneness is not just "faith", which means "attestation by default". Because such a faith merely consists of an incidental and psychological state, abstract knowledge and though. But competence on oneness is a state and a quality that occurs in the nafs because of oneness. Besides, the purpose of worshiping and actions is to acquire the ability to obey and submit, to relieve your heart from things that keep you busy other than God, and to reach the level of divineness. ${ }^{67}$ Our thinker has claimed that such competence and level can be reached by the ability of inner observation/inspiration.

Inspiration is to educate and cleanse the nafs by methods such as abstinence, dhikr, and practice, in order for knowledge to directly occur in the nafs. ${ }^{68}$ For this, powers such as imagination, ideas, and memory must be inactive, to begin with. These powers overrule the direct conceive, as they are in conflict with it. Thanks to the acquittal of the nafs and dhikr, nafs gets cleansed from material and sensory relations, the curtain of senses is removed, and the nafs ascends from the science level to şuhîd (witnessing holy secrets) level. Hence an individually unique process of acquiring knowledge begins and the form of spiritual beings reflect that person. The knowledge acquired about the world of spirit and angels is called inspiration. ${ }^{69}$

Ibn Khaldun has stated that the cognition zone of inspiration is not limited to what can be known through senses and reason. ${ }^{70}$ According to him, truths that cannot be understood by other people can be conceived, and some events can be predicted before they happen thanks to inspiration. ${ }^{71}$ Sufis go into a life of abstinence for such a conceiving to occur in themselves, reaching to the point of removing bodily powers and senses, even the ideas on their minds. This abstinence causes an indescribable pleasure in them; rational arguments cannot cause such a cognition and pleasure. ${ }^{72}$ While

\footnotetext{
${ }^{67}$ İbn Haldûn, Mukaddime, trans. Süleyman Uludağ, 824.

${ }^{68}$ Ibn Haldûn, The Muqaddimah, 1: 171.

${ }^{69}$ İbn Haldûn, Mukaddime, trans. Süleyman Uludağ, 954.

${ }^{70}$ Ibn Haldûn, The Muqaddimah, 1: 155-156.

${ }^{71}$ Ibn Haldûn, The Muqaddimah, 3: 52-53; İbn Haldûn, Mukaddime, trans. Zakir Kadiri Ugan, 2: 545-546.

${ }^{72}$ Ibn Haldûn, The Muqaddimah, 2: 343; İbn Haldûn, Mukaddime, trans. Süleyman Uludağ, 954.
} 
Peripatetic Philosophers defended that the pleasure that comes from the knowledge, and therefore the conceiving of divine beings can be reached through the theoretical reason, Ibn Khaldun argues that it would be reached with inspiration.

According to Ibn Khaldun, people who read the world of spirit and angels from the works if Ibn Sina, from Organon of Aristo, and the works of Ibn Rushd who annotated his other books and try to move from there and the arguments in there so as to conceive, end up increasing the disrupting factors, instead of having such pleasure. The baseline of philosophers on this subject is the principle of "if the active reason let someone connect with it, this happiness causes pleasure in that person". Because the active reason is the first of spiritual levels, and the curtains of sensual conceiving open up and spiritual beings are conceived thanks to it. What is implied by connecting with the active reason here is the scientific cognition. However, this is a wrong approach, since it would not take place without opening curtains of sensual conceiving. ${ }^{73}$ Since Ibn Khaldun views the reason as insufficient in comprehending the world of spirit and angels, he accepts inspiration as a implement of cognition that is beyond the reason, able to comprehend what it cannot. Inspiration takes part in first rank in his hierarchical classification of human knowledge sources.

Ibn Khaldun compares with the difference between the state that occurs as a result of inspiration and the knowledge provided by the theoretical reason with the difference between "speech" (kavl) and living by that speech and making that a quality of the nafs (to become qualified/ittisaf). Another comparison of his is the difference between knowing that helping orphans and desperate people is a means to get closer to God in theory and to achieve this quality by putting it into practice. Again, according to him, the difference between "becoming qualified with oneness" and to acquire knowledge about it is similar. The knowledge that occurs as a result of becoming qualified is much more reliable than the knowledge before becoming qualified. As long as the theoretical information is not put into practice and the action is not constantly repeated, one cannot move from abstract information to becoming qualified. As a result of repeating the action innumerable times, quality becomes proficiency; qualification and inquiry occur. The real purpose is this knowledge of state (closeness, skill) that comes out of worshipping, and competence is in that

${ }^{73}$ İbn Haldûn, Mukaddime, trans. Süleyman Uludağ, 954. 
knowledge about relevant issues according to Şâri'. Most of the knowledge of rationalist is in the level before becoming qualified. ${ }^{74}$

According to Ibn Khaldun, the purpose of religious commands is to reveal a rooted proficiency in the nafs. Thanks to this proficiency, an necessary knowledge occurs in the nafs; oneness and faith are just that. There are various levels of faith, and the lowest of those levels is an attestation in the heart which is appropriate to the acknowledgment of the tongue. Absolute faith, which is the most superior one, rises out of attestation in heart and actions that are appropriate to it and makes other organs subjected to itself as a quality that encompasses the heart. When such a faith is proven at heart, it is hard to act against it. ${ }^{75} \mathrm{Ibn}$ Khaldun views the practice as required for reaching epistemological certainty on issues related to faith. In other terms, one cannot reach a definite certainty about a belief that remains in the theoretical levels and is not put into practice. Thus, practices of faith are what makes judgments about principals of belief certain in an objective way.

Ibn Khaldun has stated that the nafs comes back to the body after acquiring knowledge about the metaphysical universe via inspiration, as it is in the revelations. Upon returning to the body, the nafs unites with matter and expresses the knowledge it acquired in material powers. ${ }^{76}$ But language is not a sufficient implement for expressing this knowledge. Since this universe is a cognate zone, things that are said on truth and its exploration are subjective, and cannot be understood by those with a different experience. Scientific terminology remains inadequate in expressing these experiences. ${ }^{77}$ Therefore, the acceptance of the knowledge acquired by inspiration is completely an issue about conscience. ${ }^{78}$

From the explanations made up to this point, it is seen that the sources that provide the knowledge about the world of spirit and angels are revelations and inspiration according to Ibn Khaldun. Are these two sources completely identical or is different? The connection prophets make with the world of spirit and angels does not depend on them, they already have that capability innately; while inspiration experts achieved this with their own

\footnotetext{
74 İbn Haldûn, Mukaddime, trans. Süleyman Uludağ, 824.

${ }^{75}$ İbn Haldûn, Mukaddime, trans. Süleyman Uludağ, 825.

76 Ibn Haldûn, The Muqaddimah, 3: 66-67.

77 Bedir, “İbn Haldûn'un Gözüyle Nakli İlimler”, 229.

78 İbn Haldûn, Tasavvufun Mahiyeti (Şifâu's-Sâil), 107.
} 
wills and efforts. That's why the relation of inspiration experts with that universe is lacking of and weak, and what they express is not perfect and certain as what prophets expressed. ${ }^{79}$ The fact that prophets received revelations, and therefore, the fact that their relations with the metaphysical universe was not an acquired ability but it was innate, are shown as the guarantee of the certainty of their knowledge. Capabilities of those other than prophets are acquired, and the knowledge they present about the metaphysical universe cannot be accepted as certain.

The fact that it is possible to connect with the world of spirit and angels through personal effort and exercises, raised the question whether it is possible for members of other religions to do that or not. According to Ibn Khaldun, even if it is possible for members of other religions to have this kind of experience, the reliability of the knowledge that is acquired in this way depends on the worship and dhikr in Islam. Moreover, he stipulated that the one that does the inspiration must be pious and in the right way, accept a sheikh as a guide, seclude oneself, and have a strong will. Inspiration without these stipulations cannot go beyond personal opinion, let alone being the truth, as it is in magicians, Christians etc. ${ }^{80}$

By accepting living according to the commands of the religion of Islam as the trueness criterion of the truth that is acquired by inspiration, religious experience claims that occur in different forms in other religious traditions are attempted to be invalidated. But members of each religion can base the same argument on the same reason, claiming that their own religious experiences are valid, and others are superstitious. Therefore, this type of statements will persist in a vicious circle and won't reach a conclusion, as long as they are not analyzed and inquired according to rational and scientific criteria. If this field is deprived of the reason that provides definite and objective information about physical, psychological, social, moral fields and left to subjectivism; suspicions about this type of knowledge lacking of certainty and scientific content will not end, on the contrary, they will increase. At the same time, the fact that there is not a common experience on this issue, and the fact that members of each religion have their own holy experience, will open the door for relativism and skepticism. Therefore, information based on religious experience would not be popularly claimed to be sufficient in providing knowledge on

\footnotetext{
${ }^{79}$ Uludağ, İbn Haldûn, 123; Bedir, “İbn Haldûn'un Gözüyle Nakli İlimler”, 228-229.

80 İbn Haldûn, Tasavoufun Mahiyeti (Şifâu's-Sâil), 132-135.
} 
extrasensory entities and basing their trueness by itself, without being subjected to scientific and philosophical evaluation.

While Ibn Khaldun did not view the reason as a sufficient source in acquiring knowledge on the metaphysical universe, he accepted inspiration/religious experience - which is the method of Sufis - and even accepted dreams as a source that provides knowledge on that universe. According to him, dreams are the nafs's ascension to the universe of meaning and comprehension of shapes and forms of beings on that universe. Since this occurs without will and request, it is not possible for people to dream whatever they want. Even if everyone has the ability to dream, not everyone can see precise dreams. Since the curtain of external senses presents an obstacle on the way of activating this ability, it must be removed. Sleep is an innate feature that is granted to humans by God, for the curtain of external senses to be opened. Since the connection of the nafs with material and external powers is disrupted while sleeping, it reaches the same level as spiritual beings. Thus, it can conceive angels and abstract beings. ${ }^{81}$ Ibn Khaldun sees the fact that it is possible to acquire knowledge about the metaphysical universe in dreams as an evidence of it being also possible outside of dreams.

Ibn Khaldun views human nafs as one in terms of a kind but classifies them into three groups according to their ability to connect with the metaphysical universe. The first one is nafs who are far from connecting with the metaphysical universe as their nature. These nafs incline toward things that are inferior, what can be perceived with imagination and senses; they acquire knowledge through senses, experience etc. The second one is nafs who incline to the spiritual universe through the intellect and focus on inspiration. Thanks to the capability they acquire, these can directly comprehend the spiritual universe without needing senses or reason. This is the level that will be reached by saints and holy people after death. The third one is the nafs of prophets, who innately have the ability to ascend to the spiritual universe. These nafs actively ascend to the level of angels by their nature, even if for just a moment. Thus, they have the opportunity to conceive the supreme universe within its own environment and conditions,

\footnotetext{
${ }^{81}$ Ibn Haldûn, The Muqaddimah, 1: 161-165; İbn Haldûn, Mukaddime, trans. Zakir Kadiri Ugan, 1: 255-257.
} 
to directly hear God's word (kalam), and they are honored with holy revelations. ${ }^{82}$

$\mathrm{Ibn}$ Khaldun classified that the nafs of prophets who directly acquire knowledge about the physical world in a different category than the nafss of other people, but also added the nafs of oracles, the enlightened, those who look toward God (nazır), ehl-i zecr, ehl-i tark, those who are in love-crazed (mecnun), and those who are sleeping to the second category with the nafs of those who practice inspiration. ${ }^{83}$ Since he did not mention philosophers under this category, he must have put them in the first category.

The fact that Ibn Khaldun accepts experience and reason as sources that provide knowledge about objects, and revelations and inspiration as sources that provide knowledge on the world of spirit and angels, also reflected on his perception of science. According to him, philosophy/rational sciences are products of the intellect and common heritage of humanity. These are sciences that directly provide knowledge on existence such as Philosophical Sciences, Physics (Tabiiyyât), Theology (Metaphysics); and aiding sciences such as Logic and Mathematics. Transferred/preached sciences are science that is preached by hosts of religion and learned by people through transference. These are Fiqh, Method of Fiqh, Kalam (Theology) and Sufism, along with Qur'an and Hadith sciences. While humankind established rational sciences, the role of transferred sciences is limited with comprehension activity. Its function here is to tie detailed issues $\left(f e r^{\prime} i\right)$ to the essential by syllogism. There are no common points whatsoever between these sciences in terms of source, subject, structure, purpose, and development line. ${ }^{84}$

According to Ibn Khaldun, the reason is benefited from while basing transferred sciences, but it is not based upon. The reason shall become aware that it cannot reach to any conclusions in transferred subjects, that it can neither accord nor conflict with revelations. Philosophy shall leave behind theological-metaphysical speculations and give up its claims in religion's field, and the transference shall limit itself with what is stated in sharia. When the reason leaves the field of revelations, it will also give up its claim to comprehend the object as a whole and to know the ultimate causes of the

\footnotetext{
${ }^{82}$ Ibn Haldûn, The Muqaddimah, 1: 155-156.

${ }^{83} \mathrm{Ibn}$ Haldûn, The Muqaddimah, 3: 110.

${ }^{84}$ Ibn Haldûn, The Muqaddimah, 2: 343; Bedir, “İbn Haldûn'un Gözüyle Nakli İlimler", 226229; Arslan, İbn Haldûn'un İlim ve Fikir Dünyası, 467.
} 
object. As long as it does not give that up, it will attempt passing from sensible to extrasensory, and reach suspicious theses that cannot be confirmed. Then, philosophers must choose between the two: Either philosophy will limit itself with the sensible and reach necessary some theses that are accepted by everyone or attempt to pass from sensible to extrasensory and fill with suspicious theses that cannot be confirmed. ${ }^{85}$

Although Ibn Khaldun has claimed that he is only objecting to theology (metaphysics) field of philosophy and that he is not against other fields of philosophy, ${ }^{86}$ it is also witnessed that he has objected to rational physics. According to him, the cause for lack of argument in Physics, the suitability which between mental consequences and external things is not certain and necessary that are claimed to be based on syllogism and definition. These are certain mental, universal and general decisions, but external senses achieve individuality with their own matter. This matter may contain things that present an obstacle for mental universal opinions to be in accordance with individual external existence. The evidence of such accordance would come from sensory observation and conceiving, not from logical arguments. And that shows that there is no certainty in what they claim to be certain. ${ }^{87}$

In Ibn Khaldun's criticism toward philosophers, it is seen that his religious reservations and Ghazali's criticism toward philosophy is also effective, along with philosophical and epistemological reasons. ${ }^{88}$ From his attitude, it is understood that he is somewhat aware of and continuing the criticism Ghazali directed at philosophers in Tehâfutu'l-felasife. But there is no sign of him being aware of Ibn Rushd's answers to Ghazali and the thesis he has formed. ${ }^{89}$ His religious reservations caused him to express that those who want to learn philosophy shall first learn transferred sciences such as hermeneutics and fiqh, and shall stay away from philosophy without fully

\footnotetext{
${ }^{85}$ Arslan, İbn Haldûn'un İlim ve Fikir Dünyası, 512-515; Öktem, “İbn Haldûn'un Felsefe-Din İlişkisine Bakışı", 68-69.

86 İbn Haldûn, Mukaddime, trans. Süleyman Uludağ, 86.

${ }^{87}$ Ibn Haldûn, The Muqaddimah, 2: 341-342; İbn Haldûn, Mukaddime, trans. Süleyman Uludağ, 952.

${ }^{88}$ For information see., Kamil Sarıtaş, “Gazzâlî’nin Akıl Tasavvurunun İbn Haldûn'da Yansıması Sorunu", Marife: Dini Araşttrmalar Dergisi 14/2 (2014), 43-62.

${ }^{89}$ Arslan, İbn Haldûn'un İlim ve Fikir Dünyası, 351; Öktem, “İbn Haldûn'un Felsefe-Din İlişkisine Bakışı", 67-70.
} 
learning these sciences..$^{90}$ The criticism Ghazali directed at philosophy in Tehâfutu'l-felasife and his declaration of philosophers as unbelievers played a determinant role in attitudes of thinkers that came after him toward philosophical sciences. The fact that he has found the rational and philosophical method insufficient for basing issues related to holiness and afterlife, one of the reasons of the decline in rational sciences is counted.

\section{CONCLUSION}

Ibn Khaldun, who evaluated sources of knowledge and the accuracy and the reliability of information that comes from them, hierarchically has classified sources of knowledge. He accepted senses as sources that provide knowledge on the sensual world, the reason as a source for the intelligible world, inspiration, and revelations as sources for the metaphysical universe. He separated himself from Peripatetic Philosophers and placed himself against them while claiming that it is not possible for the reason -which provides definite knowledge about sensual issues and issues of the intelligible- to reach definite knowledge in the field of theology. He has limited the activity field of our cognitive abilities with objects that are on the same existence plane as we are. Thus, he has directed the tendency of the theoretical reason and the interest of rational sciences about the metaphysical universe toward social facts and events. He rejected the possibility of rational metaphysics by accepting the reason's activity in the extrasensory universe as an empty endeavor. And he has recognized the reason as the ultimate authority in rational and social fields that it provides definite and accurate information to; such as logic, mathematics, history, and politics. Therefore, while criticizing the reason and rejecting the possibility of rational metaphysics, in a way, he blazed the trail for Immanuel Kant, who lived approximately four centuries later and was accepted as a milestone in the intelligible history of the West with his criticism toward rationalism and rational metaphysics, starting from the Renaissance.

While Ibn Khaldun concentrated on transference and left the reason completely out of the metaphysical universe, he did not assume a fideist attitude and left this field completely to faith. Because his effort here is to highlight the faith that is deep and insightful, against a faith that is merely an abstract acceptance and information. While Peripatetic Philosophy accepted that the reason as the source that would take us to such a faith, he

${ }^{90}$ Ibn Haldûn, The Muqaddimah, 3: 112. 
accepted inspiration. Therefore, he has attributed more importance to mystical experience than the reason or sensible experience. Even though rational and logical proofs that were asserted about metaphysical beings does not carry the same weight as the proofs in positive and mathematical sciences, it would not be true to say that the reason does not have any role in this field. The reason, at the least, has the power to determine which alternative explanation of this universe is a rational explanation. We don't have ability than the reason that can be decisive on this matter anyway. Besides, the reason is resorted to while determining which different religions and mystical doctrines are the truths. Otherwise, religions and metaphysical systems must be accepted without examining if they hold the truth or not; which would take us to fideism.

\section{BIBLIOGRAPHY}

Ardıç, Nurullah. "İbn Haldûn ve Weber'de Bilgi ve Bilim Sorunu". Geçmişten Geleceğe İbn Haldûn Sempozyumu içinde. İstanbul: İsam Yayınları, 2006, 235-253.

Arslan, Ahmet. İbn Haldûn'un İlim ve Fikir Dünyası. Ankara: Kültür Bakanlığı Yayınları, 1987.

Arslan, Ahmet. İbn-i Haldun. İstanbul: İstanbul Bilgi Üniversitesi Yayınları, 2014.

Aster, Emest Von. İlkçă̆g ve Ortaçă̆ Felsefe Tarihi. trans. Vural Okur. İstanbul: İm Yayınları, 1999.

Bedir, Murteza. “İbn Haldûn'un Gözüyle Nakli İlimler”. Geçmişten Geleceğe İbn Haldûn Sempozyumu içinde. İstanbul: İsam Yayınları, 2006, 219-233.

Canatan, Kadir. “İbn Haldûn'un Eğitim Sosyolojisi”, Eski Yeni 3 (2006), 57-65.

Cevizci, Ahmet. Felsefe Terimleri Sözlüğ̈̈̈. İstanbul: Paradigma Yayınları, 2003.

Ebu Zeyd, Mina Ahmed. el-Fikru'l-kelamî inde İbn Haldûn. Beyrut: el-Müessesetü'l-Câmi`a, 1997.

Ev, Hacer Âşık. "İbn Haldûn ile John Locke'un Epistemoloji ile İlgili Bazı Görüşlerinin Karşılaştırılması”. Ankara Üniversitesi Eğitim Bilimleri Fakültesi Dergisi 43/2 (2010), 89122.

Fârâbî, Ebu Nasr. "Felsefenin Temel Meseleleri". İslâm Filozoflarından Felsefe Metinleri içinde. trans. Mahmut Kaya. İstanbul: Klasik Yayınları, 2003.

Fârâbî, Ebu Nasr. Ârâu ehli'l medîneti'l fâdıla ve mutedâddâtihâ. tkd. Ali Bû Mulhim. Beyrût: Dâr ve mektebetu'l hilâl, 1995.

Ibn Haldûn. Ebu Zeyd Abdurrahman bin Muhammed. The Muqaddimah. enq. Abdüsselam eşŞeddâdî, b.y. Dâru'l-beydâ, 2005.

İbn Haldûn. Mukaddime. trans. Süleyman Uludağ. İstanbul: Dergâh Yayınları, 2017.

İbn Haldûn. Mukaddime, trans. Zakir Kadiri Ugan. İstanbul: MEB Yayınları, 1997.

İbn Haldûn, Ebu Zeyd Abdurrahman bin Muhammed. Tasavvufun Mahiyeti (Şifâu's-Sâil). trans. Süleyman Uludağ. İstanbul: Dergah Yayınları, 1998.

İbn Rüşd, Ebu'l Velid Muhammed. Faslu'l-makâl fî mâ beyne'l-hikmeti ve'ş-şerî̀ati mine'l-ittisâl. enq. Muhammed Ammar. Kahire: Daru'l mea'rif, 1119.

İbn Sînâ, Ebu Ali Hüseyin b. Abdullah. Dânişnâme-i alậ̂-alâı̂ hikmet. trans. Murat Demirkol. ed. Gürbüz Deniz. İstanbul: TC Türkiye Yazma Eserler Kurumu Başkanlığı Yay., 2013.

İbn Sînâ, Ebu Ali Hüseyin b. Abdullah. Necat. nşr. Muhyiddin Sabri Kurdî. Kahire: y.y. 1938. 
İbn Sînâ, Ebu Ali Hüseyin b. Abdullah. De Anima. nşr. Fazlur Rahman. London: y.y. 1970.

Meçin, Mahmut. "İhvân-ı Safâ'da Bilgi, Bilim ve İlimlerin Sınıflandırılması". Dicle Üniversitesi İlahiyat Fakültesi Dergisi 16/1 (2014): 427-458.

Sarıtaş, Kamil. “İbn Haldûn'da Bilgi Felsefesi”. Turkish Studies 9/8 (2014): 733-750.

Sarıtaş, Kamil. “Gazzâlî’nin Akıl Tasavvurunun İbn Haldûn'da Yansıması Sorunu”. Marife: Dini Araştırmalar Dergisi 14/2 (2014): 43-62.

Şulul, Cevher. "Metafiziğin Tarihsel Evrimi". Harran Üniversitesi İlahiyat Fakültesi Dergisi 11/5 (2003): 57-69.

Tanrıverdi, Hasan. "İbn Haldûn'un Vahiy Anlayışı". İnsan ve Toplum Bilimleri Araştırmaları Dergisi 5/1 (2016): 66-85.

Öktem, Ülker, “İbn Haldûn'un Felsefe-Din İlişkisine Bakışı”. Kayg̨ Uludă̆ Üniversitesi FenEdebiyat Fakültesi Felsefe Dergisi 22 (2014): 65-74.

Uludağ, Süleyman. İbn Haldûn. Ankara: TDV Yayınları, 1993.

Ülken, Hilmi Ziya. İslam Düşüncesi. İstanbul: Ülken Yayınları, 2005. 